\title{
Eroticism and Mysteries of Cross-Dressing: Increasing Trends of Male to Female Cross-Dressing in Pakistani Society
}

\author{
Quratulain Farooq, \\ M.Phil. (English Literature), Minhaj University Lahore, Pakistan
}

\begin{abstract}
Human beings are born with certain gender identities: male, female, or intersex variations. These identities have their peculiar attributes, affiliations, and psychological needs. Our social norms impose strict rules on female and male, but the protesters are always present in every society. In third-world Pakistan, with long-upheld standard Islamic and established historical social values, people have concrete models in their minds about gender roles. This article specifically deals with males who rebel against the social construct of gender roles. The research encompasses male-to-female (MTF) cross-dressing in the Sufism order within the subcontinent. It encodes the life of Sufi mystic poets of the subcontinent like Ameer Khusro, Khawaja Nzaam ud Din, Bulleh Shah, and Shah Anayat as well as today's Pakistani cross-dressers. The male tendency for adopting female attributes is called autogynephilia-it leads a man to cross-dress as a female. This article is particularly dealing with MTF (male to female). The paper discusses evidence of MTF cross-dressing in literature, drama, and theatre. It intends to value the theories of psychologists about male tendencies of cross-dressing. It evaluates the experience of real life cross-dressers in the Pakistani and western societies. The research discusses the eroticism of this transvestitism. This fetish transvestitism also has its erotic impact on both viewers and the cross-dresser.
\end{abstract}

Keywords: MTF cross-dressing, autogynephilia, gender identity in Sufi poetry, fetish transvestitism, eroticism

\section{Introduction}

MTF cross-dressing is becoming more evident nowadays all over the world. Cross-dressers exist even in Pakistani society. There are many different kinds of cross-dressers who have their own different reasons for adopting these behaviors. Cross-dressing is mostly a matter of comfort or style, personal preference for clothing associated with the opposite sex, to shock others, or 
challenge social norms. This revolves around values of the male-dominated patriarchal society, or it is used to gain access to places or resources they would not be able to reach normally.

There are girls who dress like men, and there are men who dress like women. The society either mocks at them or looks at them with contempt. If a woman dressed as a man, it is thought to be an attempt to gain masculinity and authority. Usually, in literature, reality shows, theatre, and film, male cross-dressers have been painted as laughing stocks, rather than mere drag queen. This is because in most parts of the world, it remains socially disapproved for men to wear outfits traditionally associated with women. At least for the most part, there are no attempts at understanding their psychology and feelings.

This research article is an attempt to explore motives behind cross dressing, its sensation, and satisfaction. It is more than needed in our societies so that we may understand these cross-dressers and accept them as respectable members of our society.

That said, it is worthy of note that cross-dressing is grounded in a highly logical and universal desire: the wish to be, for a time, the gender one admires. Dressing like a woman is not only dramatic, it is essentially reasonable. Apart from English Literature readers, most of us must have heard the name of William Shakespeare. In early modern literature, perhaps the most known evidence of a man dressing as a woman is in The Merry Wives of Windsor. His plays Taming the Shrew, Twelfth Night, Merchant of the Venice, etc. show the trends of female-to-male cross-dressing. Those women crossdressed to get masculine privilege and liberty.

While man to woman cross-dressing is considered to be a decline of the man's masculinity or virulent Murdandgi (manhood), there are also erotic reasons behind this transvestitism; stuffed bras, to create a firm and shapely chest, proper fitting pair of underwear, rear padding to create the illusion of a round and voluptuous booty, and different type of sexy lingerie like thongs, lacy briefs, and boy shorts. Fetish transvestite put on panties or stockings to masturbate or derive sexual enjoyment. Heterosexual males burn with intense sexual arousal and they also make hot the blood of other males.

Cross-dressing in stage plays has its deep-rooted history in English literature as well as in Asian literature. Gender disguise has been used by women and girls to pass as male and by men and boys to pass as female. Gender disguise has also been used as a plot device in storytelling, particularly in narrative ballads, and is a recurring motif in literature, theater, and film.

In history, some women cross-dressed to take up male-dominated or male-exclusive professions, such as military service. Some men cross-dressed to escape from mandatory military service. In theatre and in reality shows, MTF cross-dressing, particularly, is often used for comic effects onstage and 
on-screen. Drag is a special form of performing art based on the act of crossdressing. A drag queen is usually a man who performs as an exaggeratedly feminine character, wearing a showy dress, high-heeled shoes, obvious makeup, and wig. This type of tendencies is called autogynephilia in which men desire to change their bodies into facsimiles of the persons or things to which they are sexually attracted; it is explained as a male's propensity to be sexually aroused by the thought of him as a female.

Autogynephilia seems as a sexual orientation in that it involves elements of idealization and attachment as well as erotic desire. Nearly $3 \%$ of men in Western countries are experiencing severe manifestation of autogynephilia. Cross-dressing in different societies shares some grounds that are transvestism and gay tendencies but they have also many points of departures.

\section{Literature Review}

The following literature view is based on the study of the researches, journals, books, articles elaborating the phenomenon of MTF cross-dressing available on multimedia. It describes the relationship of each work with current research. It interprets prior research to identify the similarities between the two researches to reveal any gap that exists in the literature.

Exaerde and Kerchove (2001) say cross-dressing among men in western societies has been studied from two major perspectives throughout the twentieth century: medical and social. The medical view has mainly focused on the origin of transvestite behavior and how it could be 'cured'. Sociologists take another position. They approach transvestism as the expression of a 'personal identity'. Cross-dressing and several perspectives regarding this phenomenon deserve the attention of this study.

Bullous (1974) says Cross-dressing among men in western societies has been studied from two major perspectives. One comes from behavioral psychologists and psychiatrists who regard transvestism as deviant behavior that requires counseling and treatment. Cross-dressing has also been studied from a social scientific perspective that views transvestism in relation to the performance of gender. Male transvestites challenge assumptions about gender practices in the context of everyday life when expressing their 'dedoublement' that juxtapose masculinity and femininity.

Transvestism is thus an attack on the very notion of gender deviance, which is being mounted by small groups of otherwise very 'ordinary' men. Transvestites, by asserting 'feminine within the masculine', seriously transgresses the ideology of masculinity. Herr (1984) states in her article One Good Turn Deserves Another": Theatrical Cross-Dressing in Joyce's "Circe" Episode: "it is notable that dramatic transvestism was especially in vogue during the late nineteenth and early twentieth century's, when sexual 
impersonation was tolerated poorly, if at all, in routine social settings, and when the theatre functioned as a refuge for those phenomena like crossdressing that Victorian and Edwardian society wanted to see as having no more substance than theatrical illusions".

Cross-dressing and psycho-biological aspects have also been explored in certain research. Marcino (1986) surveys that majority of the cross-dressing aptitudes developed in early childhood. Usually, when parents come to know that their boy child is gay, they hide it and try to dress him up like a boy. This forced dressing creates psychological problems for the child. The child becomes unsure of his identity and the society does not accept him. People sexually misuse them. In different countries, an extremist of a different religion would kill this kind of children.

Chess (2016) in her book analyzes male to female and female to male cross-dressing in Early Modern literature and said "cross dressing has an erotic of its own, a queer heterosexuality that is separate from same-sex or oppositesex desire, encompassing and excluding both". The book particularly dealt with the question of relational gender expression and it sees cross-genders' relationship with other characters. Chess traced how "MTF sex and courtship scenarios allow an exploration of sexuality that, outside of the paradigms of male-female, male-male, or female-female erotic encounters, instead highlights the availability of an early modern eroticization of the queer gender. Chess shows us how, whether it is a male character or a female character who trains their desiring gaze upon the MTF character, such situations suggest that "cross dressing has an erotic of its own, a queer heterosexuality that is separate from same-sex or opposite-sex desire, encompassing and excluding both".

Hauk (2017) clarifies by her case study of mostly personal stories of biological males, a number of TV shows and movies that introduce us to the male to female (MTF) individual in a more positive way than a prostitute who has been murdered. By applauding those books and shows; she said these books and shows gave us an education and create a potential for normalcy, just as the introduction of gay and lesbian literature, in TV and movies. However, they lacked in giving an understanding of cross-dressing. Ms. Hauk presents a mature look, as the cover indicates A look inside the minds of nontransitioning cross dressers and the women who love them. She speaks from personal experience in relationship with a woman and those experiences of other couples whom she knew. The book discussed general public perception about cross-dressing, personal stories including her own, her relationship with her partner (Jen), and ties together thoughts on masculinity vs. femininity.

She said that "Please understand that trying to discover who we are as cross dressers is an impossible task if you can't take a serious hard look inside yourself'. The book is about positive and constructive ways to strengthen a relationship with cross-dressers talking about identity. She says it is a complex 
constellation of experiences, cultural and social acceptances, and our identity as a whole that shift throughout life. She finalizes that there is nothing morally wrong in MTF cross-dressing.

The article about MTF cross-dressing in 'The School of Life' (2019) (a global organization helping people to lead more fulfilled lives) scrutinizes that MTF seems as a failure. If a man shows his interest in wearing silk dresses, high heels, or likes the feel of bra around his breast, he is considered abnormal. However, in reality, the longing to cross-dress is grounded in normal human logical and universal desire - a wish to be the gender one admires more.

Cross-dressing as a woman is based on curiosity. A man wants to feel the sensation of waxed body, a sensation to be kissed like a woman. He gets a great fascinating satisfaction by being admired in front of the mirror. Crossdressing can be his protest against gender boundaries a person is born into. Cross-dressing is a principle as described by the Roman playwright, "I am human, and I think nothing human is alien to me". According to Dr. Joseph Merlino (2008), cross-dressing by itself is not a psychological problem, unless it interferes with a person's life. He supposed, "For instance...I'm a crossdresser and I don't want to keep it confined to my circle of friends, or my party circle, and I want to take that to my wife and I don't understand why she doesn't accept it, or I take it to my office and I don't understand why they don't accept it, then it becomes a problem because it's interfering with my relationships and environment".

Christine questions in Sex/Gender Transition and Life-Changing Aspiration whether it is right to mask one's true desire to cross any gender limits. A man may feel exhausted by his own identity. She compares changing one's sex or gender identity to other kind of life-changing personal transformation and projects like altering one's nationality, religion, or choice to becoming musician, parent, or getting an education. She says that we don't regard this choice to change to be abnormal based on how we perceive transformations of one's gender attributes.

\section{Research Methodology}

The research applied qualitative and quantitative research methods. Pakistani cross-dressers, historical Sufi poets, novel, drama, and researchers were the primary focus to examine mysteries of MTF cross-dressing. Respective books, articles, and research thesis were explored for help and guidance. Case study method is applied and different events, decisions, periods, projects, policies, institutions, or other systems were studied. Also, survey was done to show the authentic presence of cross-dressing and its response from Pakistanis. 


\section{Pakistan and Cross-Dressing}

This article discusses MTF (male-to-female cross-dressing) especially with Pakistani reference. The Pakistani society is based on Islamic values. The wearing of female clothing and jewelries and silken dresses are strictly forbidden in Islam. Our social norms also do not allow a man to dress like a woman. If a man attempts such, society mock at him and declares him hijra (Transgender). Some boys, who have been living under the influence of girls since their childhood, also become fond of girlish characteristics. MTF crossdressers face harassment and are abused. In spite of these facts, we see these cross-dressers dancing in theaters, films, and TV and uploading their blogs on social media. One may meet them on signals knocking the glass windows of cars and begging to make their both ends meet. They dance under the money shower of rich lords who like to show off. They also earn money by blessing new born babies. This type of cross-dressing is comparatively tolerated because they lap dance between the drunken guests fulfilling their lust of seeing female bodies dancing. It also gives them a sense of superiority to their endowers. People in Pakistan don't like to talk about this phenomenon, or, in fact, it is a taboo to show someone their likings to dress up like female.

Geographically, Pakistan is part of a subcontinent, a land rich in great Muslim mystics and Sufis. The poetry of these poets has been a source of inspiration for its successor. The great Sufi poets, the likes of Nizam ud din Auliya, Ameer Khusro (died 1325), Bulleh Shah (1680-1758), and Shah Inayat, dissolved gender identities through their poetry and sometimes personal appearance. In the 18th century, Punjab Baba Bulleh Shah (16801758), a Sufi saint, raised voices against the oppressive institutions of the society and questioned the very basis of everything that was taken for granted. In fact, in his own life, Bulleh Shah at every step openly resisted every norm that demanded from him to shape his individuality upon a model approved by the society. It is said that Bulleh Shah once gave himself a completely effeminate appearance by putting on plaits in his hair. Pivoting on his heel, he danced in ecstasy to please his master Shah Inayat. His non-conformity displeased the religious figures and he was ridiculed for dancing and staying with hijras (eunuchs).

Bulleh put on the garb of a woman, got hold of a sarangi (a musical instrument), learned dancing from a dancing girl and became adept in it. He then took along with him a drummer and a harmonium player and went to the tomb of a holy man in whose memory an annual function was being celebrated. Shah Inayat had also come to attend it. While all other dancers and singers got tired and sat down, Bulleh, in ecstasy, continued to dance. Ameer Khusro once danced in women's clothes in front of his Sufi master. Musa Sada Sohag wore a woman's clothes and bangles for the rest of his life and he fully rejected the patriarchal birthright of being male. This queer sexual orientation 
was permanent transgression against gender norms. Some researchers considered them homosexual. However, this article is an effort to prove that these Sufi poet female traits were to show their submissiveness, meekness, dedication, and devoutness to their Murshad (spiritual master). This is because women of that time used to and must, say, be forced to obey their male masters in the guise of father, brother, husband, and son.

Here are some expressions of some real life cross-dressers from Pakistan society.

The cross-dressers do not share common reasons for their tendency. It varies from fun-seeking to economic oppression. The two cases of Pakistani cross-dressers reported in mainstream media can illustrate this reality. Akram (2015) lives in the northern Punjab city of Rawalpindi, Pakistan. He is a mobile accessories salesman at an alleyway shop and struggles to make a living. "I am not transgendered. I am a man who simply enjoys dancing and needs money to have a better life, and being a woman is the way. One job is not enough to help me and my family."

Riasat Hussain spoke to a news photographer: "Across conservative Pakistan, where Islamic extremists launch near-daily attacks and many follow a strict interpretation of their Muslim faith, male cross-dressers and the transgendered face a challenge of balancing two identities" (Muheisen, 2015). Some left their villages for the anonymity of a big city, fearing the reactions of their families while still concealing their identity from neighbors and coworkers.

The Pakistani society is not favorably disposed toward cross-dressers and they undergo difficult situations all their lives as they know that they aren't normal by birth or got that way with time. Media and fashion industries have a place for cross-dressers that seems well-fitting, and they feel comfortable in this strata. Oftentimes, these cross-dressers find a suitable working environment in beauty parlors and with women dress designers.

Eroticism is a quality that is the reason of sexual feelings and a philosophical contemplation concerning the aesthetics of sexual desire, romantic love, and sensuality. It may be in any form of artwork, including painting, sculpture, photography, drama, film, music, or literature. In Pakistani society, we have both homosexual and heterosexual cross-dressers. Their cross dressing sometimes becomes transvestic fetishism in which men experience recurrent, intense sexual-arousing fantasies, urges, or behaviors. Male cross-dressing might occur on the basis of arousal of fantastic orgasms. For a male who is attracted to women, a person looking like a woman must be an attraction to him. In our society, female tend to be the lessexpressive sex partners; thus, the man who has strong sex desire would rather visit these cross-dressers. 
The article also focuses on the Pakistani writers who dared to write something about MTF cross-dressing. There are a few writers and researchers who worked on this tendency so far. This article brings into light the work of those Pakistani writers. This article also debates over the first Pakistani crossdresser's talk show The Late Night Show with Begum Nawazash Ali, the character of Sameer in the drama serial Ishq Zaha Naseeb, and the character of Shahid in The Black Album by Hanif Kureshie plus the reference of some real life cross-dressers.

Shahid, being a son of cross-cultural marriage, is a victim of identity crisis. Exhausted from the battle of Western and Islamic culture, Shahid chooses to live for the moment and for himself and rejects the exhortations of politics and religion. Shahid's cross-dressing gives him sensational satisfaction. In Ishq Zaha Naseeb, the character of Sameer crosses dresses at every night in a close room to satisfy his childhood impact and psychological needs.

Ali Salim (2008), best known by his alter-ego Begum Nawazish Ali, South Asia's first cross-dressing television host, said concerning Nawazish that "She's every woman's inspiration and every man's fancy". Salim's show was a revolutionary change for television viewer of an Islamic society. According to Salim, the show gave a light, frivolous face to Pakistan - in contrast to the images of poverty, fanaticism, and abuse of women. "Every time I turn on BBC or Fox News, there are bombs going off in Pakistan. It's so pathetic. However, we are a people with a rich culture and a rich tradition. And we are people who just want to have fun," he said. "That's why people relate to the show. She does things others will never do," Salim said. "But my only agenda is love. Live life to the fullest, and live it to the best".

Hanif Kureishi is a British playwright, filmmaker, screenwriter, and novelist of Pakistani and English descent. In 2008, The Times included Kureishi in their list of "The 50 greatest British writers since 1945", based on his talk about this male inclination toward the feminine in The Black Album, 1995. It is a common thinking that we all get our 'identity' by birth and it cannot be changed. This is no more a valid fact in today's multicultural world. The Black Album by Hanief Kureshie (1954, age 65 years) examines the influence of multicultural postcolonial Briton on Shahid's personality. Kureshie portrays an erotic blur of the character of Shahid (the main character) who is torn between his fanatical friends and a multicultural love affair in postcolonial Britain. He meets Deedee, a young cultural studies lecturer, and gets involved in an experimental love affair. Shahid undergoes a transition from his Pakistani ancestry to his desired identity as a Briton. In this pursuit of transformation, he experiences male-to-female cross-dressing that gives him liberation from his fundamentalism. Deedee encourages Shihid's continuous reshaping of his erotic self and she makes Shahid to explore his 
new female identity. "He liked the feel of his new female face. He could be demurred, flirtatious, teasing a star; a burden went, a certain responsibility has been removed. He did not have to take a lead. He even wondered what it was like to go out as a woman, and be looked at differently." In the novel, Shahid wears a female identity to break the monotony of his life; and it is a sign of revolt against his own self.

A popular Pakistani drama Ish zaha Naseeb by Hashem Nadeem deals with one of the main lead, Sameer's split personality. It subtly shows how he is just like any other normal person, but with a little secret attached to it. He is obsessed at his childhood maid's memory and every night, he dresses up like her. However, one thing she finds a little odd about Sameer's personality is that his other side only shows up at specific times, whereas people with multi personality disorder obviously are not in control of themselves to be so systematic with fixed schedules. Sameer is a wealthy handsome young businessman whose mother abandoned him when he was a child and his father died. He was then raised by his step-mother. In his past, he went through some traumatic experiences that caused him to develop a split personality disorder, which has been kept a secret between Sameer and his step-mother. Shakira (Sameer's maid) intentionally spoils his personality by sexually abusing his childhood to take revenge of an alleged killing of his son. He got engaged to a girl named Zoya who he thought would help him get over his issues, but she died mysteriously. Some believe Sameer killed her, while others believe she committed suicide. Sameer gets married to a girl Gohar, his poor employee. Sameer solves all financial issues of Gohar's family. Gohar after marriage not only accepts Sameer's personality disorder but also her unconditional love tries to comfort him.

Dr. Hasan, Dr. Subhani, and Ms. Osman (2012) dealt with the issue of cross-dressing in Pakistani society and analyzed that cross-dressing or transvestism is apparently increasing over the years and is changing the society of today. The research explains the issues of cross-dressers and their behavior. It targets an intriguing question: 'Does Islamic society accept this behavior?'. Mostly, cross-dressers are not homosexual and these identities have developed an alter-ego within their own selves and they are completely in love with a part of their own self. The research also dealt with the issue: "Is cross-dressing a sin or an inspiration?"

In Hinduism, cross-dressing is degradation or not normal. They are not regarded and respected as a normal human being and given illicit work to do to earn their living. In Islam, through the passage of Hadith, it can be said that an individual who acts as cross-dresser and is not by birth is a sinner and, also, the person who had innate qualities to act and behave like a woman but is a man and gets involved in immoral activities in the society is also a sinner. In Christianity, it is not accepted if a man dresses as a woman and a woman 
dresses as a man. The article is an effort to prove that besides the financial reasons, there are facts about MTF cross-dressing. A man may wish to adopt female ways of dressing, wearing make-up, nail paint, bras, silken dresses, and it can be a natural trend of mind. These men are neither transgender nor mentally sick in any way.

\section{Result and Findings}

A survey was conducted to get proportionally different trend of MTF cross-dressing. Sampling is done from different age group and professions, teen college, boys and girl, adults, lawyers, doctors, teachers, musicians, dancers, and stage performers. The survey contained the questions below.

1. MTF (male to female) cross-dresser is hijrah or transgender, gay, homosexual.

Yes $70 \% \quad$ No $30 \%$

2. MTF (male to female) cross-dressers are mentally sick or have some psychological issue.

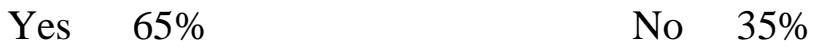

3. MTF (male to female) cross-dressing is a matter of personal choice and he is a respected member of the society as anyone else.

Yes $50 \% \quad$ No $50 \%$

4. MTF cross-dressers arouse your erotic feelings.

Male Yes $90 \%$ and $10 \%$

Female: Yes 5\% and No 95\%

5. Why is cross-dressing increasing in Pakistan?

People are becoming more open minded $\quad 40 \%$

People are forgetting the values of Islam $60 \%$

6. Do you allow as a Pakistani your loved one (son, brother, boyfriend, husband, friend) MTF cross-dressers to show their likings about female attributes openly?

$\begin{array}{ll}\text { Yes } 1 \% & \text { No } 99 \%\end{array}$

According to the survey, $70 \%$ of people think cross-dressers are hijrah (transgender), $65 \%$ think they have some kind of mental disorder or psychological issue. Also, 99.9\% of responders say they would not allow their loved ones (son, brother, boyfriend, friend, husband) to wear female dress. Then, $60 \%$ believe that the reason for the increasing trends of cross-dressing is because those who practice same are forgetting that, by the ways of Islam, cross-dressing is considered as a sin, while $40 \%$ believes that this tendency is increasing because of open-mindedness and liberalism. Although $90 \%$ male say that MTF cross-dressers arouse their erotic feelings, on the contrary, $10 \%$ 
feel their gestures disgusting. MTF cross-dressing is more common in hidden practice in Pakistan.

The survey showed that business professionals, doctors, lawyers, blue collar and white collar, are all involved in it and it has nothing to do with financial status. It is also a myth that cross-dressers are homosexual, bi-sexual, or transgender. Most cross-dressers are heterosexual men and, in fact, heterosexual cross-dressers are rather more common than homosexual or bisexual cross-dressers.

The desire to wear female clothes, especially sexy underwear, bras, has the same origin as the impulsion for sexual penetration. By this transvestite fetish act, majority of men gets a perfect orgasm. MTF cross-dresser not only arouse their own sex organs but also that of their viewers. The dancing bodies of these cross-dressers directly play with the sensations of males. In Pakistani society, women do not dance openly so men. As a result, men are not able to see them. However, when they see male wearing all those fanciful bras and panties, they feel a sexually arouse.

\section{Conclusion}

Human beings are different by nature. They have different tendencies towards the opposite gender. Some female want to wear male dresses to get the liberty and power associated to males, while some males like to wear female attributes to relish the privilege of being effeminate. The desire of MTF cross-dressing is based on different reasons for different males. On stage, film, drama, MTF cross-dressers are mostly presented as 'drags'. It can be a psychological disorder of split personality, too. It also has its financial reasons and is a type of rebellion to break the monotony. The most important point of this paper is that MTF cross-dressing is a matter of choice-as natural as someone having their own likes and dislikes for edibles. Wearing womanish dresses and getups does not make a man less masculine. Transvestitism has a reason rooted in sexual arousal and satisfaction. Although transvestitism is deep-rooted in Sufism, people do not admit that they are MTF cross-dressers openly.

\section{References:}

1. Aronson, J. (2007). Quoted in Tina Kelly, "A Stir, but No Crisis, from Principal's Gender Change," New York Times, athttp://www.nytimes.com/2007/09/10/education/

2. Bauer, H. (2013). Women \& Cross Dressing 1800-19. Rout ledge.

3. Bullough, L. (1974). Transvestites in the Middle Ages. American Journal of Sociology, 79, 6, 1381-139 
4. Chess, S. (2016). Male-to-Female Cross-dressing in Early Modern English Literature: Gender, Performance, and Queer Relations. Rout ledge.

5. d'Exaerde, C.D.K. (2001). "Dedoublement": the negotiation of gender in transvestism (Doctoral dissertation, Durham University).

6. Griffin, E. (2015). Inside the Double Lives of Pakistan's CrossDressing Men, MarieClaire.com https://www.marieclaire.com/culture/news/a13482/cross-dressingmen-in-pakistan-photos/

7. Hauk, S. (2017), Living with Cross-dressing: Defining a New Normal, https://www.amazon.com/Living-Crossdressing-DefiningNewNormal/dp/0991470230

8. Herr, C. (1984). "One Good Turn Deserves Another": Theatrical Cross-Dressing in Joyce's" Circe" Episode. Journal of modern literature, 11(22), 63-276.

9. Juhász, T. (2011). Writing Gender: Literary Identity Politics in Hanif Kureishi's The Black Album.

10. Kugle, A.S. (2007). Sufis and Saints' Bodies: Mysticism, Corporeality, and Sacred Power in Islam, University of North California Press.

11. Marciano, T. D. (1986). "How Do You Know I'm a Woman?": Freeing Up Role Constraints in Sexual Diversity. Teaching Sociology, 14(3), 191-92.

12. Merlino, J. P., Jacobs, M. S., Moritz, K. L., \& Kaplan, J. A. (Eds.) (2008). Freud at 150: 21st-century essays on a man of genius. Jason Aronson.

13. Mirza (2019). https://reviewit.pk/ishq-zahe-naseeb-episode-18-storyreview-unique-script/

14. Muheisen, M. (2015). Inside the Double Lives of Pakistan's CrossDressing Men, MarieClaire.com https://www.marieclaire.com/culture/news/a13482/cross-dressingmen-in-pakistan- photos/

15. Rehan, S. (2008). "Star-trek: "I get to have the best of both worlds," Ali Saleem". Newsline Pakistan. http://web.archive.org/web/20080401055345/http://www.newsline.co m.pk/NewsJan2006/startrekjan.htm. Retrieved 2008-05-07.

16. Subhani, M.I., Hasan, S.A., \& Osman, A. (2012). Cross-Dressing: A curse or an inspiration?. European Journal of Social Sciences, 33(1), 150-154.

17. Why would I be a cross dresser. https://www.quora.com/Why-woulda-straight-man-be-a-crossdresser adresshttps://broadblogs.com/2014/10/01/men-wearing-dresses-tofeel-whole/ 